\title{
Ebola: A Crisis in Global Health Leadership
}

Lawrence O. Gostin

Georgetown University Law Center, gostin@law.georgetown.edu

Eric A. Friedman

Georgetown University Law Center, eaf74@law.georgetown.edu

This paper can be downloaded free of charge from:

https://scholarship.law.georgetown.edu/facpub/1381

http://ssrn.com/abstract=2509858

384 Lancet 1323-1325 (2014)

This open-access article is brought to you by the Georgetown Law Library. Posted with permission of the author. Follow this and additional works at: https://scholarship.law.georgetown.edu/facpub

3 Part of the Health Law and Policy Commons, Health Policy Commons, International Public Health Commons, Public Policy Commons, and the Virus Diseases Commons 


\section{Ebola: a crisis in global health leadership}

The Ebola epidemic will take hundreds of thousands of lives if the current trajectory is not reversed. ${ }^{1}$ Fear has gripped the most affected countries: Sierra Leone instituted a national lockdown, ${ }^{2}$ Liberia cordoned off swathes of territory, ${ }^{3}$ and in Guinea, panicked residents in one village killed a team that had come to raise awareness about the disease. ${ }^{4}$ WHO, with its budget and capacity to respond diminished, has largely been sidelined in the response to Ebola. In a leadership vacuum, high-income countries sent in military assets, the UN Security Council declared Ebola a threat to international peace and security, and UN SecretaryGeneral Ban Ki-moon created a special UN mission. How did this situation arise, and what will it take to bring Ebola under control and prevent future crises? The answers lie in failures of leadership.

WHO should be the global health leader. Under its constitution, WHO was envisaged as "the directing and coordinating authority on international health work". In describing WHO's mission recently, however, DirectorGeneral Margaret Chan said it is a "technical agency", with governments having "first priority to take care of their people". ${ }^{6}$ Yet the affected states possess fragile health systems that have proven unable to prevent Ebola's domestic and transnational spread. WHO itself is constrained. Its budget is incommensurate with its responsibilities, with an operating budget a third of the US Centers for Disease Control and Prevention's budget. ${ }^{7.8}$ After a 2011 funding shortfall, WHO cut its already insufficient budget by nearly US $\$ 600$ million. ${ }^{8}$ The organisation's emergency response units were reduced, with some epidemic control experts leaving the agency. ${ }^{9}$ Furthermore, WHO controls only $30 \%$ of its budget, and member states have co-opted WHO's agenda through earmarked funds. . $^{8,10}$

In preparing its budget, WHO relied on misplaced confidence that it could mobilise funds rapidly in the face of a crisis, but waiting for donations has led to costly delays. WHO has been constantly catching up in mobilising resources for Ebola: in April, 2014, it sought $\$ 4.8$ million, by July 31 it set a $\$ 71$ million goal; ${ }^{11}$ and in August made a $\$ 490$ million appeal, with the UN launching a $\$ 988$ million appeal weeks later. ${ }^{12,13}$

WHO oversees the International Health Regulations $(\mathrm{IHR}){ }_{1}^{14}$ which require 196 states parties to develop public health capacities to detect and respond to public health emergencies of international concern (PHEIC), with states required to cooperate in building these capacities. However, the regulations do not provide incentives, sanction states for failing to cooperate, or allocate responsibility. In 2011, after the 2009 H1N1 influenza PHEIC, an independent Review Committee warned that "The world is ill-prepared to respond... to a global, sustained and threatening public-health emergency", with health capacities "not now on a path to timely implementation worldwide". ${ }^{15}$ Huge capacity deficits remain and, for some low-income countries, no data are even reported in WHO's global database. ${ }^{16}$ WHO itself did not implement the Review Committee's proposal for a rapid-response emergency fund. ${ }^{15}$

WHO declared Ebola a PHEIC on Aug 8, triggering temporary non-binding recommendations. ${ }^{17}$ Some countries imposed travel bans, contrary to WHO's recommendations. Affected states, moreover, could not realistically implement WHO recommendations for treatment centres, health worker compensation, and personal protective equipment. ${ }^{17}$

The delayed and fragmented response to Ebola left a vacuum, which led to an unlikely plea from Médecins Sans Frontières for military deployment-logistics, engineering, and supply-chain management. ${ }^{18}$ On Sept 16 , US President Barack Obama announced a military-led response in Liberia, ${ }^{19}$ which could shore-up capacity but will not fill major governance deficits, which require UN action.

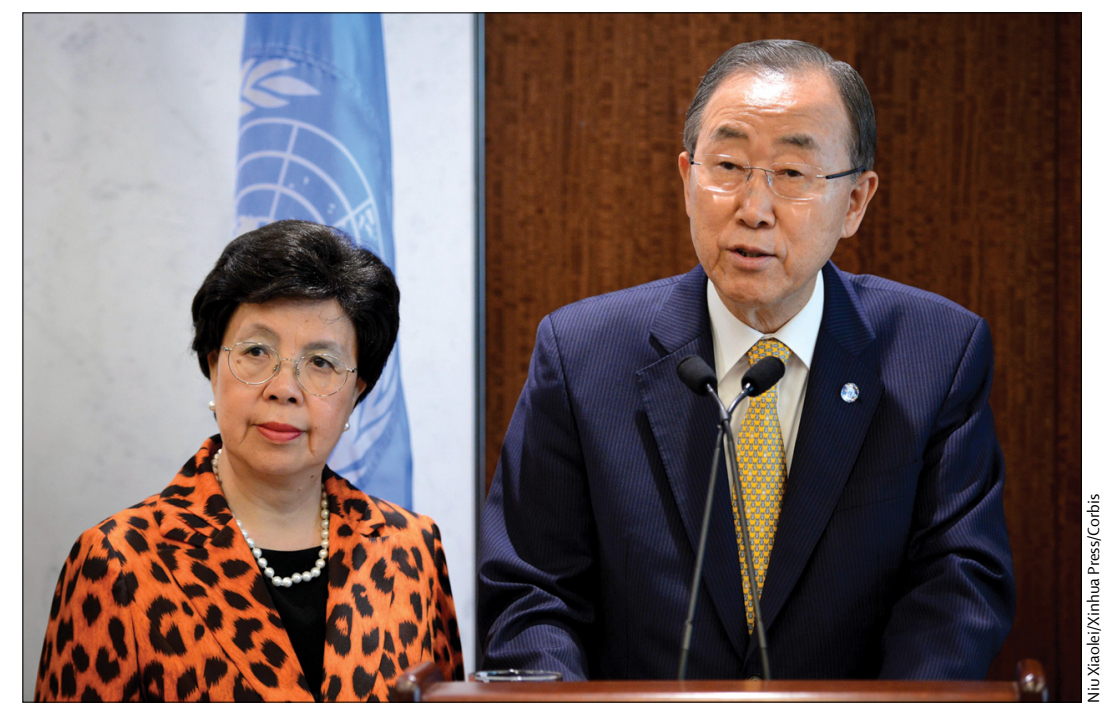

Published Online October 7, 2014 http://dx.doi.org/10.1016/ S0140-6736(14)61791-8 See Editorial page 1321 See Comment page e49 
The UN has the legitimacy and authority that nationstates lack. The UN Security Council is charged with maintaining international peace and security and, under article 25 of the UN Charter, member states are required to carry out its decisions. The Security Council's Sept 18 resolution on Ebola ${ }^{20}$ was the second time it had responded to a health crisis, after HIV/AIDS resolutions in 2000 and 2011. The Security Council concluded the Ebola epidemic could reverse peacekeeping and development gains, at a time when Liberia and Sierra Leone are recovering from destructive civil wars and a UN peacekeeping mission remains in Liberia. The unanimous resolution called on member states to deploy medical assets, expand public education, and end travel bans. Although the resolution left unclear the exact duties required of states, the Security Council powerfully urged state action, while raising the political profile of Ebola in ways WHO could not. The resolution also requested the Secretary-General to ensure that other UN agencies act, including those in health, development, and human rights, to ensure an allsector UN response. Along with the Security Council's action, the Secretary-General established a UN Mission for Ebola Emergency Response ${ }^{21}$ to lead the operational response and provide strategic direction; a Special Representative, Anthony Banbury, heads the mission, reporting to Ban Ki-moon.

The UN Secretary-General must act decisively to specify state responsibilities, set priorities, and coordinate activities. Resources need to be mobilised swiftly to build treatment facilities, train health workers, secure supply chains, and educate the public about Ebola. Ban Ki-moon should identify and engage states that do not provide their fair share of resources or take Ebola resources from existing commitments-for example, by redirecting contributions to Ebola from the Global Fund to Fight AIDS, Tuberculosis and Malaria or the GAVI Alliance.

The UN Security Council must continually monitor the Ebola response, and, if necessary, adopt further resolutions with unambiguous binding authority and clear allocation of responsibility. It should also be prepared to intervene in future epidemics-interpreting its mandate broadly to encompass human security. A PHEIC should be sufficient grounds for UN Security Council action, which would bolster WHO by giving greater legal force to its actions.
The Ebola crisis should become a turning point for WHO reform, and for its member states being willing to fully resource it. No agency can exert leadership when it controls only a small portion of a depleted budget. The World Health Assembly should substantially increase members' assessed contributions, create an emergency contingency fund, reform its regional organisation, and engage non-state actors. ${ }^{22}$ Along with supportive member states, strategic leadership requires an organisational ethos that embraces WHO's promise as the leading global health authority. WHO's mission is tied to national health capacities, so it should negotiate an international health systems fund. ${ }^{23} \mathrm{~A}$ bolder vision would be a Global Fund for Health. ${ }^{24}$

Failures in leadership have allowed a preventable disease to spin out of control, with vast harms to social order and human dignity. If the Ebola epidemic does not spur major reforms, it will undermine the credibility of WHO and the UN, and enable the conditions for future crises to persist. Major failures in governance and leadership could be repaired if lessons are learned from Ebola. The UN Secretary-General and WHO Director-General should jointly commission a high-level independent commission to review what went wrong and how to prevent future global health emergencies. The commission's mandate should include: ample resources and political will to fulfil WHO's global mission; effective functioning of the IHR; the UN's responsibilities in a global health emergency; sustainable health system financing; calibrating the military's role when public health is overwhelmed; and scientific research and ethical allocation of vaccines and medicines.

The world needs a strong $\mathrm{WHO}$, with the financing and political influence to fulfil its historic mission. The Ebola outbreak should push political actors to enact the far-reaching reforms needed. Global health leadership can be built, but only if genuine leaders choose to build it.

\section{*Lawrence O Gostin, Eric A Friedman}

O'Neill Institute for National and Global Health Law, Georgetown University Law Center, Washington, DC 20001, USA gostin@law.georgetown.edu

LOG is Director of the World Health Organization Collaborating Center for Public Health Law and Human Rights. EAF declares no competing interests.

1 Meltzer Ml, Atkins CY, Santibanez S, et al. Estimating the future number of cases in the Ebola epidemic-Liberia and Sierra Leone, 2014-2015. MMWR Surveill Summ 2014; 63: 1-14 
2 Nossiter A. Lockdown begins in Sierra Leone to battle Ebola. The New York Times Sept 20, 2014. http://www.nytimes.com/2014/09/20/ world/africa/ebola-outbreak.html (accessed Oct 2, 2014).

3 McNeil Jr DG. Using a tactic unseen in a century, countries cordon off Ebolaracked areas. The New York Times Aug 13, 2014. http://www.nytimes. com/2014/08/13/science/using-a-tactic-unseen-in-a-century-countriescordon-off-ebola-racked-areas.html (accessed Oct 2, 2014).

4 Callimachi N. Fear of Ebola drives mob to kill officials in Guinea. The New York Times Sept 19, 2014. http://www.nytimes.com/2014/09/19/ world/africa/fear-of-ebola-drives-mob-to-kill-officials-in-guinea.html (accessed Oct 2, 2014).

5 WHO. WHO constitution (1946). http://whqlibdoc.who.int/hist/official_ records/constitution.pdf (accessed Oct 3, 2014).

6 Fink S. WHO leader describes the agency's Ebola operations The New York Times Sept 4, 2014. http://www.nytimes.com/2014/09/04/ world/africa/who-leader-describes-the-agencys-ebola-operations.html (accessed Sept 29, 2014).

7 CDC. Budget request summary-fiscal year 2015. Atlanta, GA: US Centers for Disease Control and Prevention, 2014. http://www.cdc.gov/fmo/topic/ Budget\%20Information/appropriations_budget_form_pdf/FY2015 Budget_Request_Summary.pdf (accessed Oct 2, 2014).

8 WHO. Proposed programme budget 2014-2015. Geneva: World Health Organization, 2013. http://apps.who.int/gb/ebwha/pdf_files/WHA66/ A66_7-en.pdf (accessed Sept 28, 2014).

9 Fink S. Cuts at WHO hurt response to Ebola crisis. The New York Times Sept 3, 2014. http://www.nytimes.com/2014/09/04/world/africa/cuts-atwho-hurt-response-to-ebola-crisis.html (accessed Sept 28, 2014).

$10 \mathrm{WHO}$. Annex to the financial report and audited financial statements for the year ended 31 December 2013. Geneva: World Health Organization, 2014. http://www.who.int/about/resources_planning/AnnexA67-43-en. pdf (accessed Sept 29, 2014).

11 WHO, Governments of Guinea, Liberia, and Sierra Leone. Ebola virus disease outbreak response plan in west Africa. Geneva: World Health Organization, 2014. http://www.who.int/csr/disease/ebola/evd-outbreakresponse-plan-west-africa-2014.pdf (accessed Oct 2, 2014).

12 Painter K. Ebola outbreak could strike 20,000 , WHO says. USA Today Aug 29, 2014. http://www.usatoday.com/story/news/world/2014/08/28/ who-ebola-deaths/14725155/ (accessed Oct 2, 2014).
13 UN. Ebola virus disease outbreak: overview of needs and requirements. New York: United Nations, 2014. https://docs.unocha.org/sites/dms/CAP/ Ebola_outbreak_Sep_2014.pdf (accessed Oct 2, 2014).

14 WHO. International Health Regulations (2005) second edition. Geneva: World Health Organization, 2008. http://whqlibdoc.who.int/ publications/2008/9789241580410_eng.pdf?ua=1 (accessed Oct 4, 2014)

15 WHO. Report of the Review Committee on the Functioning of the International Health Regulations (2005) in relation to the pandemic (H1N1) 2009. Geneva: World Health Organization, 2011. http://apps.who. int/gb/ebwha/pdf_files/WHA64/A64_10-en.pdf (accessed Oct 4, 2014).

16 WHO. Global Health Observatory Data Repository. http://apps.who.int/ gho//data/node.main.IHROOALLN?lang=en (accessed Sept 28, 2014).

17 WHO. WHO statement on the meeting of the International Health Regulations Emergency Committee regarding the 2014 Ebola outbreak in west Africa. Aug 8, 2014. http://www.who.int/mediacentre/news/ statements/2014/ebola-20140808/en/ (accessed Sept 28, 2014).

18 Médecins Sans Frontières. Global bio-disaster response urgently needed in Ebola fight. Sept 2, 2014. http://www.msf.org/article/global-bio-disasterresponse-urgently-needed-ebola-fight (accessed Oct 2, 2014).

19 Cooper H, Fink S. Obama presses leaders to speed Ebola response. The New York Times Sept 17, 2014. http://www.nytimes.com/2014/09/17/ world/africa/obama-urges-world-powers-to-bolster-ebola-response.html (accessed Oct 2, 2014)

20 UN Security Council. Resolution 2177 (2014). New York: United Nations, 2014. http://www.un.org/en/ga/search/view_doc.asp?symbol=S/ RES/2177\%20(2014) (accessed Sept 28, 2014).

21 UN Security Council, UN General Assembly Sixty-Ninth Session. Ebolaidentical letters dated 17 September 2014 from the Secretary-General to Security Council/General Assembly. UN Doc. A/69/389-S/2014/679. Sept 18, 2014. http://www.un.org/en/ga/search/view_doc. asp?symbol=A/69/389 (accessed Oct 2, 2014).

22 Gostin LO. Global health law. Cambridge, MA: Harvard University Press, 2014

23 Gostin LO. Ebola: towards an International Health Systems Fund. Lancet 2014; published online Sept 4. http://dx.doi.org/10.1016/S01406736(14)61345-3

24 Ooms G, Hammonds R. Financing health through a Global Fund for Health? London: Chatham House, 2014. http://www.chathamhouse.org/ publications/papers/view/197444 (accessed Oct 2, 2014). 